Military Technical College Kobry El-Kobbah, Cairo, Egypt

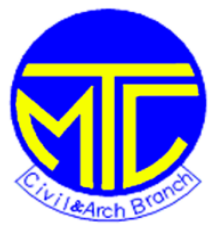

$8^{\text {th }}$ International Conference on Civil and Architecture Engineering ICCAE-8-2010

\title{
SEISMIC RESPONSE OF BRICKS INFILLED REINFORCED CONCRETE FRAMES
}

\author{
By
}

Hilal A. Mahmoud *

\section{$\underline{\text { Abstract: }}$}

Bricks-filled walls are a common structural element in numerous buildings both old and new. Many of these buildings and structures are located in seismic zones, and some of these structures will fail after repeated loading. Unfortunately, since bricks infill walls are nonstructural components, very few methods exist to determine the seismic response of these walls. Since current code documents provide little recommendations for the effect of such infilled walls on the performance of RC frames. Therefore, there is a pressing need for a simple and versatile approach to predict the effects of the bricks infilled walls on the building response under seismic loads. The finite element analysis program ANSYS is utilised here owing to its capabilities to predict the effect of the infilled walls on RC frames. An extensive set of parameters is investigated including infilling, infilled wall thickness, infill walls with opening, and regularity of the infilled wall panels. The effects of the abovementioned parameters on the lateral drifts, and base shear force of RC frames are investigated. The results demonstrate the significance of the investigated parameters on the seismic response of bricks infilled RC frames. Finally, conclusions that may be useful for designers, have been drawn, and represented.

\section{Keywords:}

Infilled Walls, Reinforced Concrete Frames, Finite Element Analysis, Ansys, Diagonal Strut, Seismic Analysis, Storey Drifts, Lateral Deflection.

* Lecturer of Structural Engineering , Faculty of Eng., Zagazig University, Egypt. E-mail: hilalcivil@yahoo.com.- 


\section{Introduction:}

Many reinforced concrete (RC) frame structures have unreinforced brick infill walls to serve as interior and exterior partitions. Such construction can be found in old and new buildings. In fact, RC frames with brick infill are common construction practice in many parts of the world. However, even though unreinforced brick infill walls are often treated as non-structural components, they will interact with the boundary frames when subjected to seismic loads. The beneficial influence of infill walls in protecting a structure against seismic loads has been recognized by many engineers [1]. Extensive research work has been carried out in order to predict the influence of infill panels as it is well known that their presence modifies significantly the structural behaviour of RC buildings. The highly nonlinear response of the infilled frames even at low load level makes a linear elastic approach inadequate.

In early stage of civilization, people constructed mostly brick buildings based on low engineered and empirical approaches. In design of new buildings, the structural behaviour of brick elements is of interest mostly in case of infilled frames or mixed $\mathrm{RC}$ frames, where brick elements are also being utilized as participating in structural behaviour of the building. Behaviour of brick infill walls is difficult to predict because of significant variations in material properties and because of failure modes that are brittle in nature. As a result, brick infill walls have often been treated as nonstructural elements in buildings, and their effects are not included in the analysis and design procedure. However, experience shows that brick walls have significantly increase the initial stiffness of RC frames. Kaushik and others [12] reviews and compares analysis and design provisions related to brick infilled RC frames in seismic design codes of 16 countries and identifies important issues that should be addressed a typical model code. Very few codes have made provisions on RC frames with brick infill. Euro code, for example, considers some provisions for ordinary building up to three storeys in low seismic zones, where the Indian seismic code 1893 recommends linear elastic analysis for the bar RC frames excluding the effect of brick infill [12].

The response of a single-bay, single-storey brick infill RC frame under a lateral load in the beam level has been investigated using a specific computer program for the analysis of infilled plane frame. The basic characteristic of this analysis is that the infill-frame contact length and contact stresses are estimated as an integral part of the solution, and are not assumed [20] a simplified equation is proposed to relate the yield period of vibration of infilled RC frames was obtained [11]. A three-storey RC frame structure with different amount of brick infill walls is considered to investigate the effect of infill walls on earthquake response of these types of structures. The diagonal strut approach is adopted for modelling brick infill walls. Pushover curves were obtained for the structure using nonlinear analysis option of commercial program sap2000 [14].

An experimental research showed that the unreinforced brick infill walls in RC frame structures could provide significant lateral stiffness during seismic response provided that they are not isolated from the surrounding frame elements. These walls can lead 
to sufficient drift control until after their elastic limit is exceeded [3]. An experimental investigation was presented in which a portal frame with brick infill was subjected to monotonic loading until failure, the failed frame was then repaired using forrocement coating and then was tested again to failure. The failure load of the repaired frame was higher than that of the original frame [13]. In addition, an experimental investigation was conducted for studying the influence of brick infill walls in RC frames. The results showed that, until the cracks developed in infill, the contribution of the infill to both lateral stiffness and strength is very significant [19].

\subsection{Infilled frames:}

In buildings, different types of structures for resisting lateral loading may be utilised. One of these is the infilled frame. An infilled frame actually consists of three components, the skeletal structure, the infill, and the interface between the frame and the infill.

The frame is the main structure of a building; it consists of columns and beams. The frame can be made of reinforced concrete or steel. The connection in this skeletal structure almost behaves as hinges. This also means that the connection can be manufactured at low cost.

The infill is used to fill the area between the beams and the columns to create a façade or shear wall. It contributes to the structural behaviour of the building in combination with the frame. This contribution can be quantified for some types of infilled frames, but is usually not taken into account.

The interface between the frame and the infill is very important for the total structure behaviour of infilled frame. It determines how large the contribution of the infill to the horizontal stiffness is and how well the frame and infill co-operate as a single lateral load resisting structure. The interface can be a physical structural connection, but it also can be just the location where the frame and the infill meet in compression.

\subsection{Brick Infill Walls Numerical Models:}

Attempts at the analysis of infilled frames have yielded several analytical models. It may be convenient to classify them into macro and micro models based on their complexity. A basic characteristic of a macro (simplified) model is that they try to encompass the overall (global) behaviour of a structure element without modelling all the possible modes of local failure [20]. Micro (fundamental) models, on other hand, model the behaviour of a structural element with great detail trying to encompass all the possible modes of failure.

\section{Macro Models:}

The first attempts to model the response of the infilled bricks frame structures is using diagonal strut with appropriate geometrical and mechanical characteristics as shown in Fig. (1-a). The infill can be replaced by an equivalent pin-jointed diagonal strut made of the same thickness as the infill panel and a width equal to one third of the infill diagonal length [20]. Based on the frame-infill contact length, alternative proposals for the evaluation of the equivalent strut width. In the last two decades, it 
became clear that one single strut element is unable to model the complex behaviour of the infilled frame. Macro-models that are more complex were then proposed, but they were still usually based on a number of diagonal struts. Six compression-only inclined struts can model the infill panel; three parallel struts are used in each diagonal direction. At any point during the analysis, only three of the six struts are active, and the struts are switched to the opposite direction whenever their compressive force reduces to zero.

\section{Micro Models:}

The micro-models are based on the finite element method, using three different kinds of elements to represent the behaviour of infilled frames subjected to lateral loading. According to these models, the frame is constituted by beam element, the infill by plain shell elements, and the interface contact surface by interface elements or by one-dimensional joint elements. In addition, the infill bricks wall can be represented with a line element with non-linear shear spring at the mid of the element as shown in Fig. (1-b).

\subsection{Problem Statement :}

Exterior brick walls and interior partitions built as an infill between a reinforced concrete frame's beams and columns are usually considered to be non-structural elements in design. The interaction between the frame and infill is often ignored. However, the actual behaviour of such structures observed during past earthquakes shows that their response is often wrongly predicted during the design stage. Real interaction between the infill panel and the frame results in premature failure of the frame in some cases, and in improved performance in others.

Hence, the statement of the problem in this study is to find out the relationship between brick infill walls (infilling, infill wall thickness, infill wall with opening, infill walls regularity, and infill wall aspect ratio) and the seismic response (lateral deflections, and base shear force) of reinforced concrete framed structures.

\subsection{Objectives:}

The objective of this study was to carry out numerical simulation and parametric studies and compare them with the results of a previous experimental investigation. The study also attempted to determine the type of interaction between the infill and the frame, which has a major impact on the structural behaviour and load-resisting mechanism, and would capture characteristics of reinforced concrete infilled with brick in much more detail than a strut. It is realized that the fulfilment of the following sub-objectives would in turn fulfil the main objective:

To analyze the effect of infilling on seismic response of reinforced concrete frames.

To analyze the effect of infill wall thickness on seismic response of reinforced concrete frames.

To analyze the effect of infill wall with opening on seismic response of reinforced concrete frames.

To analyze the effect of infill wall regularity on seismic response of reinforced 
concrete frames.

\subsection{Scope:}

Finite element models were developed to simulate the seismic response of infilled frames using the ANSYS program. The analysis carried out is conducted on 28 reinforced concrete frames of identical dimensions and material properties. The study is limited to the following scopes:

1- Constant spans (3 spans), span is equals to $4.9 \mathrm{~m}$.

2- Constant height (8 stories), storey height is equals to $3.70 \mathrm{~m}$.

3- Horizontal irregularities of the infilling wall a panel is considered due to absence of infilling wall panel in particular storey bay compared to adjacent storey bay.

4- Infilling wall thickness is assumed 15, 20, 25, and $30 \mathrm{~cm}$.

5- Four cases for soft storey effect are considered.

6- Opening area ratio (opening area/infilling bay area) for the infilling panel is assumed $0.00 \%$ (no openings), 17\% (window openings), 26\%, and 34\% (door openings).

Conclusions from the current research and recommendations for future studies are included.

\section{Modeling full-size RC infilled frames :}

\section{2-1 Geometry:}

The dimensions of the RC infilled frame are shown in Fig. (2), each span of RC frame was $4.90 \mathrm{~m}$ and the storey height was $3.70 \mathrm{~m}$. The cross sectional area for both the beam and the column of the frame are rectangular with breadth $30 \mathrm{~cm}$. and depth $90 \mathrm{~cm}$. The investigated parameters include the infilling, infilling wall thickness, opening area ratio in the infill panel, and irregularities of the infilling wall panel. Details of the investigated frames and their characteristics are presented in Table 1.

Ideally, the bond strength between the concrete and the steel reinforcement should be considered. To provide the perfect bond, the link element for the steel reinforcing was connected between nodes of each adjacent concrete solid element, so the two materials shared the same nodes.

\section{2-2 Element types:}

Nonlinear finite element analysis has been carried out using ANSYS software (version 11 with civil FEM software). The RC members of the frame have been modeled with SOLID 65 element (concrete element), the reinforcing steel was modeled with LINK 8 element (link element), the infill (bricks, no consideration was given to the effect of mortar joints) was modeled with SOLID 45 element (brick element), and the connection between the RC element and infill was modeled with 
CONTAC 12 element (contact element). The finite element mesh used in the analysis is shown in Fig. (3).

\section{$\underline{\text { SOLID } 65}$}

This element has eight nodes with three degrees of freedom at each node, translations in the nodal $\mathrm{x}, \mathrm{y}$, and $\mathrm{z}$ directions. This element is capable of plastic deformation, cracking in three orthogonal directions, and crushing. The following properties must be entered in ANSYS:

Elastic modulus $\left(\mathrm{E}_{\mathrm{c}}\right)$.

Ultimate compressive strength $\left(\mathrm{f}_{\mathrm{c}}^{\prime}\right)$.

Ultimate tensile strength (modulus of rupture, $f_{r}^{\prime}$ ).

Poisson's ratio (v).

Shear transfer coefficient $\left(\beta_{t}\right)$ which is represents conditions of the crack face. The value of $\beta$ t ranges from 0.0 (smooth crack, complete loss of shear transfer) to 1.0 (rough crack, no loss of shear transfer).

\section{$\underline{\text { LINK } 8}$}

This element is a 3D spar element and it has two nodes with three degrees of freedom, translations in the nodal $\mathrm{x}, \mathrm{y}$, and $\mathrm{z}$ directions. This element is also capable of plastic deformation. The steel was connected between nodes of each adjacent concrete solid element, so the two materials shared the same nodes. The steel is assumed to be an elastic-perfectly plastic material and identical in tension and compression. The following properties must be entered in ANSYS:

Elastic modulus $\left(\mathrm{E}_{\mathrm{s}}\right)$.

Yield stress $\left(f_{y}\right)$.

Poisson's ratio (v).

\section{$\underline{\text { SOLID } 45}$}

This element is defined by eight nodes having three degrees of freedom at each node, translations in the nodal $\mathrm{x}, \mathrm{y}$, and $\mathrm{z}$ directions. This element has plasticity, and creep capabilities. The following properties must be entered in ANSYS:

Elastic modulus $\left(\mathrm{E}_{\mathrm{c}}\right)$.

Ultimate compressive strength $\left(f_{c}^{\prime}\right)$.

\section{CONTAC 12}

This element represents two surfaces, which may maintain or break physical contact 
and may slide relative to each other. The element is capable of supporting only compression in the direction normal to the surfaces and shear in the tangential direction. The element has two degrees of freedom at each node.

\section{2-3 Material properties:}

\subsubsection{Finite element model of concrete:}

The concrete is assumed homogeneous and initially isotropic. The compressive uniaxial stress- strain relationship for concrete model is obtained by using the following equations to compute the multi-linear isotropic stress-strain curve for the concrete.

$$
\begin{array}{ll}
\mathrm{f}_{\mathrm{c}}=\varepsilon \mathrm{E}_{\mathrm{c}} & \text { for } 0 \leq \varepsilon \leq \varepsilon 1 \\
\mathrm{f}_{\mathrm{c}}=\varepsilon \mathrm{E}_{\mathrm{c}} /[1+(\varepsilon / \varepsilon 0) 2] & \text { for } \varepsilon 1 \leq \varepsilon \leq \varepsilon_{0} \\
\mathrm{fc}_{\mathrm{c}}=\mathrm{f}_{\mathrm{c}}^{\prime} & \text { for } \varepsilon 0 \leq \varepsilon \leq \varepsilon_{\mathrm{cu}} \\
\varepsilon_{0}=2 \mathrm{f}_{\mathrm{c}} / \mathrm{E}_{\mathrm{c}} &
\end{array}
$$

Where:

$$
\begin{aligned}
& \mathrm{f}_{\mathrm{c}}: \text { stress at any strain } \varepsilon \\
& \varepsilon_{0}: \text { strain at the ultimate compressive strength } \mathrm{f}_{\mathrm{c}} \\
& \varepsilon_{1}: \text { strain corresponding to } 0.3 \mathrm{f}_{\mathrm{c}} \\
& \varepsilon_{\mathrm{cu}}: \text { ultimate compressive strain. }
\end{aligned}
$$

The simplified stress-strain curve for concrete is constructed from six points connected by straight lines as shown in Fig.(4-a). The curve starts at zero stress and strain. Point $1,0.3 \mathrm{f}_{c}^{\prime}$, is calculated in the linear range. Points 2,3 , and 4 are obtained from equation $1-b$, point 5 is at $\varepsilon 0$ and $f^{\prime} c$. The behaviour is assumed to be perfectly plastic after point 5 .

For concrete, input data used in this analysis:

Elastic modulus $\quad=25900 \mathrm{MPa}$.

Ultimate compressive strength $=30.00 \mathrm{MPa}$.

Ultimate tensile strength $\quad=3.00 \mathrm{MPa}$.

Poisson's ratio $\quad=0.20$.

Shear transfer coefficient $(\beta \mathrm{t})=0.5$. 
For infilling (clay bricks), input data used in this analysis:

- Elastic modulus $=6500 \mathrm{MPa}$.

- Ultimate compressive strength $=8.00 \mathrm{MPa}$.

\subsubsection{Finite element model of reinforcement:}

The steel for the finite element models is assumed to be elastic-perfectly plastic material and identical in tension and compression as shown in Fig (4-b).

For reinforcing steel, input data used in this analysis:

Elastic modulus $=200000 \mathrm{MPa}$.

Yield stress $=360 \mathrm{MPa}$.

Poisson's ratio $=0.30$

\section{2-4 Loading and nonlinear solution:}

The analytical investigation carried out here is conducted on $26 \mathrm{RC}$ infilling frames; all frames are loaded by vertical uniform loads, and seismic loads. The seismic loads are generated as per in UBC 97. The zone 3 of the code and structure foundation resting on (very dense soil and soft rock) soil Sc type has been assumed in the analysis. At a plane of support location, the degrees of freedom for all the nodes of the solid65 elements were held at zero.

In nonlinear analysis, the total load applied to a finite element model is divided into a series of load increments called load step. At the completion of the each increment solution, the stiffness matrix of the model is adjusted to reflect nonlinear changes in structural stiffness before proceeding to the next load increment. The ANSYS program uses Newton-Raphson equilibrium iterations for updating the model stiffness. For the nonlinear analysis, automatic stepping in ANSYS program predicts and controls load step size. The maximum and minimum load step sizes are required for the automatic time stepping. In the current study, the maximum load step size is determined to be $1.0 \mathrm{kN} / \mathrm{m}$ and a $0.25 \mathrm{kN} / \mathrm{m}$ load increment is specified for the minimum load step size.

\section{Analysis results and discussion:}

In total, four parameters are investigated in the current study. These are:

- Horizontal irregularities of the infilling wall panels is considered due to absence of infilling wall panel in particular storey bay compared to adjacent storey bay

- Infilling wall thickness is assumed 15, 20, 25, and $30 \mathrm{~cm}$. 
- Soft storey effect.

- Opening area ratio for the infilling panel is assumed $0.00 \%$ (no openings), $17 \%$ (window openings), 26\%, and 34\% (door openings).

\subsection{Infilling wall panels thickness and irregularities}

Figure 5 shows the effect of the infilling wall panel on lateral displacement for varies wall panel irregularity, only the wall panel thickness $15 \mathrm{~cm}$. is plotted. Due to the presence of the infill walls, there is a reduction in the displacement of the frame. This reduction in the displacement is high in case of infilling frame model (all the three bays are infilled), namely by about $69 \%$ compared with bare frame model (without infilling). The reduction in the displacement in case of medium infilling frame models (two bays are infilled) is in the intermediate range, namely about 53\% compared with bare frame model. The reduction in the displacement in case of one infilling frame models (one bays are infilled) is the least, namely about $22 \%$ compared with bare frame model.

One significant influence of infill walls on the seismic response of the frame model is the reduction of the storey drifts, as shown in Fig. 6. The reduction is because the stiffness of infilled frame is higher than that of the bar frame. Also, the reduction is high in case of infilling frame model, namely by about $87 \%$ compared with bare frame model. The reduction in case two bays are infilled is about $81 \%$, and the reduction one bays are infilled is about $68 \%$.

The base shear force versus infilling wall thickness of the various frame models are shown in Fig. 7. The results show that the increasing of infilling wall thickness leads to increasing the base shear force and this is due to increasing the total gravity loads. The total base shear force ranges from $516 \mathrm{kN}$ (about $6.6 \%$ of total gravity loads) to $548 \mathrm{kN}$ (about $7.1 \%$ of total gravity loads), for the case of all the three bays of the frame are infilled. For the case of bar frame, the total base shear was equals to 239 $\mathrm{kN}$ (about $3.1 \%$ of total gravity loads).

\subsection{Soft storey}

Open first storey (soft storey) is used in most of urban multi-storey buildings for cars parking, shop, and reception. In such buildings, the upper storey being stiff compared with the open first storey. The top lateral displacements for two different models (infilling frame and soft storey) are shown in Fig. 8 for all infilling wall thickness. The results show that the soft storey has significant effect; the top lateral displacement of the soft storey frame model is higher than that value for the infilling frame model. For infilling wall thickness $15 \mathrm{~cm}$., the top lateral displacement of the soft storey frame model is higher than that for the infilling frame model by about $128 \%$. For infilling wall thickness $30 \mathrm{~cm}$. the increasing in the top displacement is about 206\%. The effect of soft storey in the maximum storey drifts is shown Fig. 9. 
Also, the results show that the soft storey has significant effect; the maximum storey drift of the soft storey frame model is higher than that value for the infilling frame model, by about $60 \%$. The effect of the soft storey in the base shear force is shown in Fig. 10. The results show that the soft storey has insignificant effect on the base shear force.

\subsection{Opening area ratio}

Window and door openings are inevitable parts of infill walls for functional reasons. The effect of openings on the behaviour of the infilled frames under the effect of seismic loads is not taken care of by most of the codes. Hence, the behaviour of infilled frame with openings is considered in the present study. A parametric study is performed considering the opening area ratio presented by the percentage of the opening area size to the infill wall bay size (opening area ratio $=$ opening size $/$ infill bay size). Four values for the opening area ratio are considered, namely $0.0 \%$ (no openings), $17 \%$ (window openings), 26\%, and 34\% (door openings). Top lateral displacement versus the opening area ratio is shown in Fig. 11. For all opening area ratios, the top lateral displacement increased with the increase in the opening ratio. For the group of models having one bays infilling, the percentage of increasing is $21 \%$, and for the group of models having three bays infilling, the percentage of increasing is $140 \%$. The effect of opening ratio in the storey drifts is shown Fig. 12, the results show that the opening ratio has insignificant effect on the storey drift. The effect of the opening area ratio in the base shear force is shown in Fig. 13. The results show that the increasing the opening area ratio leads to decreasing the base shear force and this is due to decreasing the total gravity loads.

\section{Summary and conclusions:}

The effect of infill wall predominately changes the behaviour of the structure and it is essential to consider infill walls for seismic evaluation of the structure. The infilling wall panels in the buildings can significantly reduce the drifts. The study focuses on the consequences of the investigated parameters on the lateral deflection and the total base shear force. The conclusions made from this investigation are:

- The effect of increasing wall panels of infilled frame on the top lateral deflection is abusive: the lateral deflection decreases to be about $70 \%$ of the bar frame value.

- The significant increase in lateral displacements and storey drifts is observed with decrease of infilling wall thickness.

- In structures with a first soft storey, the upper storey being stiff undergoes less inter storey drift, while the lateral displacement will be concentrated at the first 
soft storey. Hence, an abrupt change in the stiffness in the first storey has adverse effect on the performance of the structure during seismic resistance.

- The effect of increasing the opening area ratio on the top lateral displacement is abusive for large opening area ratio (opening ratio is bigger than 30\%), the lateral displacement increases to be about $76 \%$ of value obtained for the complete infilling frame.

- It can also be concluded that the effect of opening on the behaviour of infilled frames may be neglected if the area of opening is less than $10 \%$ of the area of the infill panel, i.e., the frame is to be analyzed as a solid infilled frame. On the other, the effect of infill wall panels on infilled frame may be ignored if the area of opening exceeds $40 \%$ of the area of the infill panel, i.e., the frame is to be analyzed as a bare frame.

\section{References:}

[1] J.N. Arlekar, S.K. Jain, and C.V.R. Murty, "Seismic Response of RC Frame Buildings with Sofi First Storey" CBRI Golden Jubile Conference on Natural Hazards in Urban Habitat, 1997, New Delhi, India.

[2] D.K. BelI, and B.J. Davidson, "Evaluation of Earthquake Risk Buildings with Masomy Infill Panels", Paper number 39, NZSEE 2001 Conference, Paper No. 4-02-01.

[3] M. Saatcioglu, F. Serrate, and S. Foo, " Seismic Perfonnance of Masomy Infill Walls Retrofitted with CFRP Sheets" Natural Sciences ad Engineering Research Council of Canada (NSERC), Ottawa, Canada, 2002.

[4] F. Demir, and M. Sivri, "Earthquake Response of Masomy Infilled Frames " ECAS 2002 International Symposium on Structural and Earthquake Engineering, October 14, 2002, Ankra, Turkey

[5] Council H. Mostafaei, T. Kabeyasawa, "Effect of Infill Masomy Walls on the Seismic Response of RC Buildings Subjected to the 2003 Bam Earthquake Strong Motion: a Case Study of Bam Telephone Center" Bull Earthquake Research Institute, Tokyo University, Vol. 79,2004, PP. 133-156

[6] Das, and C. V.R Murty, "Brick Masomy Infills in Seismic Design of RC Frame Buildings: Part 2 - Behavior " The Indian Concrete Journal, August 2004, PP. 31-38.

[7] G. Magenes, and S. Pampanin, "Seismic Response of Gravity Load Design Frames with Masomy Infill" 13th Word Conference on Earthquake Engineering, Vancouver, Canada, 2004, Paper No. 4004.

[8] J. Proence, S. Oliveira, and J. Almeida, "Seismic Perfonnance Assessment of RC Structures with Masomy Infilled Panels" ISET Journal of Earthquake Technology, Paper No. 449, Vol. 41, No. 2-4, December 2004. PP 233-247. 
[9] B. Binici, and G. Ozcebe, "Seismic Evaluation of Infilled RC Frames Strengthened with FRPS " 8 thU.S. National Conference on Earthquakes Engineering, April 18-22, 2006, San Francisco, California, U.S.A., Paper No. 1717.

[10] E. Smyrou, C. Blandon, S. Antoniou, R Pinho, and H. Crowely, "Implementation and Verification of Masomy Panel Model for Nonlinear Pseudo-Dynamic Analysis of Infilled RC Frames " First European Conference on Earthquake Engineering and Seismology, Geneva, Switzerland, 3-8 September, 2006, Paper No. 355

[11] H. Crowely, and R. Pinho, "Simplified Equations for Estimating the Period of Vibration of Existing Buildings " First European Conference on Earthquake Engineering and Seismology, Geneva, Switzerland, 3-8 September, 2006, Paper No. 1122

[12] H. B. Kaushik, D. C. Rai, M. Eeri, and S. K. J "Code Approaches to Seismic Design of Masonry Infilled RC Frames: A State-of-the-Art Review" Earthquake Engineering Research Institute, Earthquake Spectra, Vol. 22, No. 4, November 2006, PP. 961-983.

[13] K. H. Amanat, M. M. Alam," Experimental Investigation of the Use of Ferrocement Laminates for Repairing Masonry Infilled RC Frames" Journal of Civil Engineering (lEB), Vol. 35-2,2007, PP. 71-80

[14] K. A. Korkmaz, F. Demir, and M. Sivri, "Earthquake Assessment of $R C$ Structures with Masonry Infill Walls" International Journal of Science Technology, Vol. 2, No. 2, 2007, PP. 155-164

[15] Nancy Lee, "Test Specimens for the Retrofit of Non Ductile RC Frames with Masonry Infill" Earthquake Engineering Symposium for Young Researchers, August 8-12, 2007, Seattle, Washington, U.S.E.

[16] S. Arulselvan, K. Subramanian, E. B. Pillai, and A. R. Santhakumar, " $R C$ Infilled Frame- RC Plane Frame Interactions for Seismic Resistance" Journal of Applied Sciences, Vol. 7,2007, PP. 942-950

[17] A. K. Hashmi, and A. Madan, " Damage F orecast for Masonry Infilled RC Framed Buildings Subjected to Earthquake in India" Current Science Journal, Vol. 94, No. 1, 10 January 2008, PP. 61-73.

[18] S. Helou, and A. Touqan, "Dynamic Behavior of RC Structures with Masonry Walls" An-Najab University Journal, Nablus, Vol. 22, 2008, PP. 77-92..

[19] Arulselvan, and K. Subramanian, "Experimental Investigation on three Dimensional RC Infilled Frame-RC Plane Frame Interactions with slab for Seismic Resistancs" American Journal of Applied Sciences, Vol. 5(4), 2008, PP.328-333.

[20] O. P. G. Asteris, "Finite Element Micro-Modellng of Infilled Frame" Electronic Journal ofStructural Engineering, Vol. 8, 2008. 
[21] G. Mondal, S. K. J and M. Eeri, " Lateral Stifness of Masonry Infilled RC Frames with Central Opening" Earthquake Engineering Institute, Eartgquake Spectra, Vol. 24, No. 3, August 2008, PP. 701-723.

[22] S. Pujol, A. Climent, M. Rodrigue and J. Pardo, " Masonry Infill Walls : An Effective Alternative for Seismic Strengthening of Low Rise Building Structures" 14 th World Conference on Earthquake Engineering, October 1217, 2008, Beijing, China.

[23] S. F. Taher, and H. M. Afefy, "Role of Masonry Infill in Seismic Resistance of $R C$ Structures" The Arabian Journal for Science and Engineering, Vol. 33, No. 2B, October 2008, PP. 291-306.

[24] A. R. Moubark, and S. F. Taher, "Effect of Reinforcing Patterns on the Behavior of Masonry Walls in RC Frames" The Arabian Journal for Science and Engineering, Vol. 34, No. 2B, April 2009, PP. 37-56.

[25] A. K. Samanta, " on Utilization of Seismic Resistance of Masonry Infills in Design of Low Rise Mixed RC Buildings- A case of Study" ARPN Journal of Engineering and Applied Sciences, Vol. 4, No. 4, June 2009, PP. 18-25.

[26] M. Leipold, And 1. Schwarz, "Modeling Techniques for RC Frame System with Infills" 18 th International Conference on the Application of Computer Scince and Mathamatics in Architecture and Civil Engineering, Weimar, Gennany, 7-9 Ju1y, 2009.

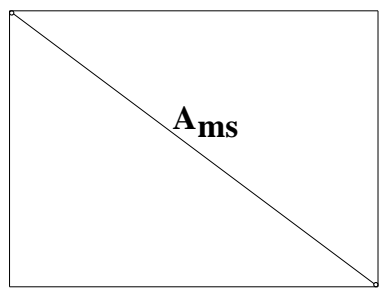

Single- strut model

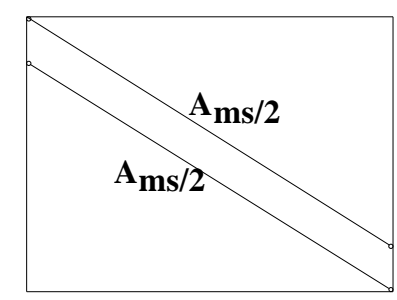

Double- strut model

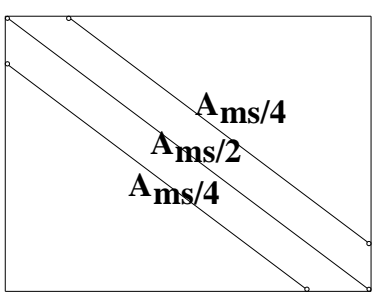

Triple- strut model

Fig.( 1-a): Different strut models.
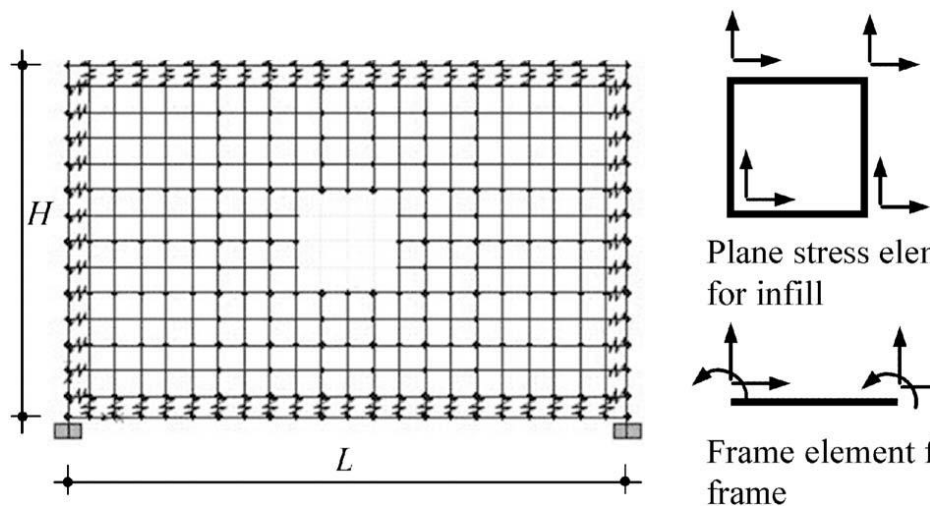

Plane stress element for infill

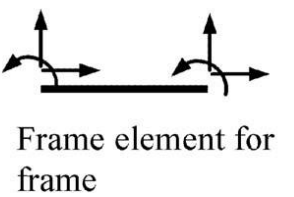

Fig. 1-b: Micro ( FEM) models. 


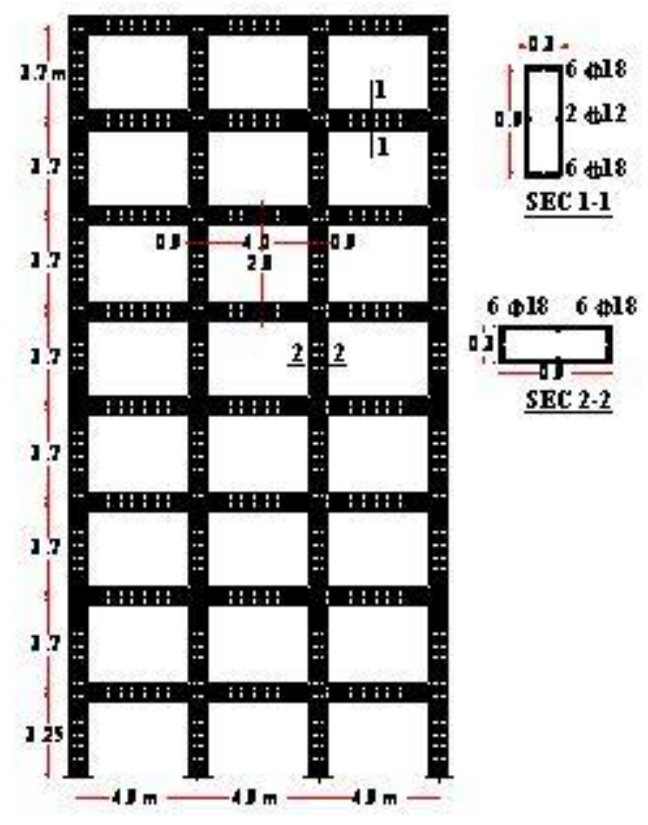

Fig.( 2): Reinforcement details of a frame.

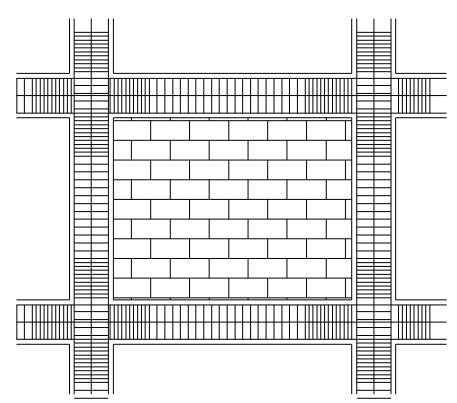

Fig. (3-a) Typical frame model.

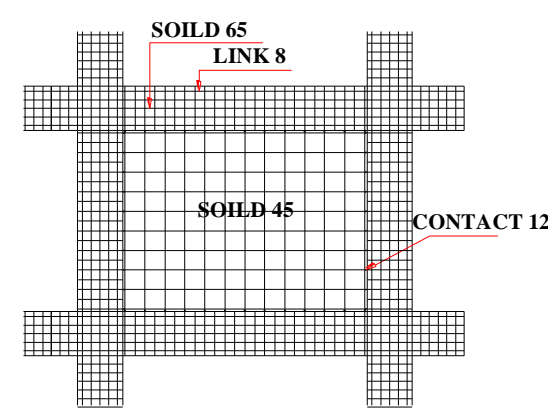

Fig. (3-b): Finite element mesh. 
Proceedings of the $\boldsymbol{8}^{\text {th }}$ ICCAE-8 Conference, 25-27 May, 2010

Table (1): Details of the investigated frames.

\begin{tabular}{|c|c|c|c|c|c|c|c|}
\hline \multirow[t]{2}{*}{ Ref. } & \multirow[t]{2}{*}{ Group } & \multicolumn{2}{|c|}{$\begin{array}{c}\text { Infilling Panel } \\
\text { Area (A) }\end{array}$} & \multirow[t]{2}{*}{$\begin{array}{c}\text { Infilling } \\
\text { Thickness cm }\end{array}$} & \multicolumn{2}{|c|}{$\begin{array}{c}\text { Opening Area } \\
\qquad\left(\mathrm{A}_{\mathbf{0}}\right)\end{array}$} & \multirow{2}{*}{$\begin{array}{c}\text { Opening } \\
\% \\
\mathbf{A}_{0} / \mathbf{A}\end{array}$} \\
\hline & & $\mathrm{L}(\mathrm{cm})$ & B (cm) & & b (cm) & I (cm) & \\
\hline FO & $\overline{\overline{\text { BAR }}}$ & 0 & 0 & 0 & 0 & 0 & 0 \\
\hline FL1 & & 400 & 280 & 15 & 0 & 0 & 0 \\
\hline FL2 & & 400 & 280 & 20 & 0 & 0 & 0 \\
\hline FL3 & & 400 & 280 & 25 & 0 & 0 & 0 \\
\hline FL4 & & 400 & 280 & 30 & 0 & 0 & 0 \\
\hline FLL1 & & 400 & 280 & 15 & 0 & 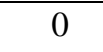 & $\overline{0}$ \\
\hline FLL2 & & 400 & 280 & 20 & 0 & 0 & 0 \\
\hline FLL3 & & 400 & 280 & 25 & 0 & 0 & 0 \\
\hline FLL4 & & 400 & 280 & 30 & 0 & 0 & 0 \\
\hline FLLL1 & & 400 & 280 & 15 & 0 & 0 & 0 \\
\hline FLLL2 & & 400 & 280 & 20 & 0 & 0 & 0 \\
\hline FLLL3 & & 400 & 280 & 25 & 0 & 0 & 0 \\
\hline FLLL4 & & 400 & 280 & 30 & 0 & 0 & 0 \\
\hline FLS1 & & 400 & 280 & 15 & $\bar{~} 0$ & $\bar{~} 0$ & 0 \\
\hline FLS2 & & 400 & 280 & 20 & 0 & 0 & 0 \\
\hline FLS3 & & 400 & 280 & 25 & 0 & 0 & 0 \\
\hline FLS4 & & 400 & 280 & 30 & 0 & 0 & 0 \\
\hline FLO1 & & 400 & 280 & 15 & 150 & 150 & $13 \%$ \\
\hline FLO2 & & 400 & 280 & 15 & 200 & 150 & $26 \%$ \\
\hline FLO3 & & 400 & 280 & 15 & 300 & 150 & $40 \%$ \\
\hline FLLO1 & & 400 & 280 & 15 & 150 & 150 & $13 \%$ \\
\hline FLLO2 & & 400 & 280 & 15 & 200 & 150 & $26 \%$ \\
\hline FLLO3 & & 400 & 280 & 15 & 300 & 150 & $40 \%$ \\
\hline FLLLO1 & & 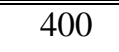 & 280 & 15 & 150 & 150 & $13 \%$ \\
\hline FLLLO2 & Fi & 400 & 280 & 15 & 200 & 150 & $26 \%$ \\
\hline FLLLO3 & & 400 & 280 & 15 & 300 & 150 & $40 \%$ \\
\hline & & & & & & & \\
\hline
\end{tabular}




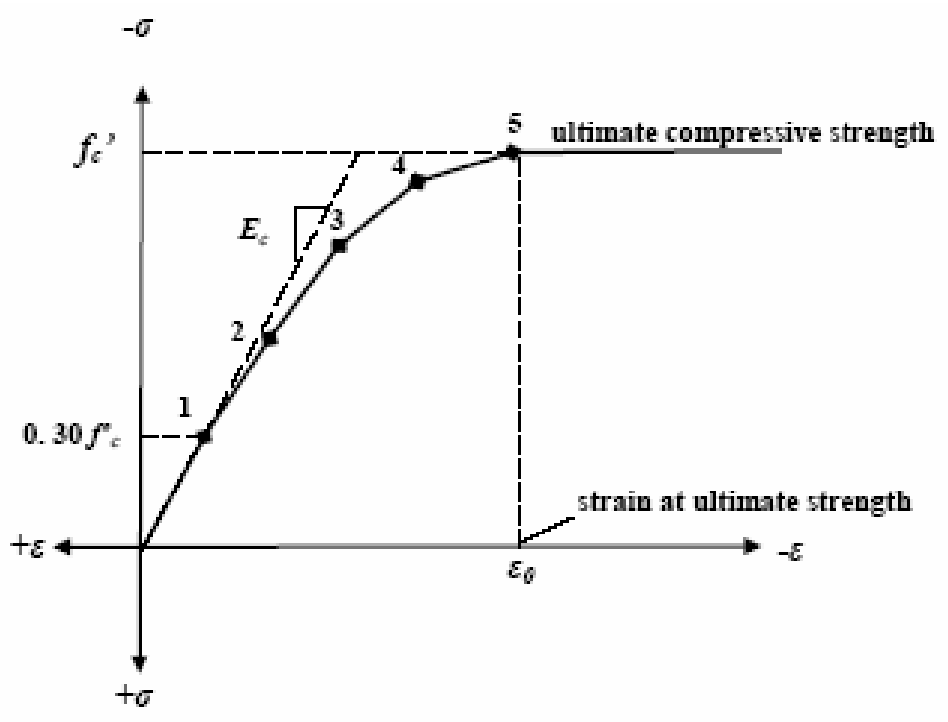

Fig. (4-a) : Simplified compressive uneasily stress-strain curve for concrete.

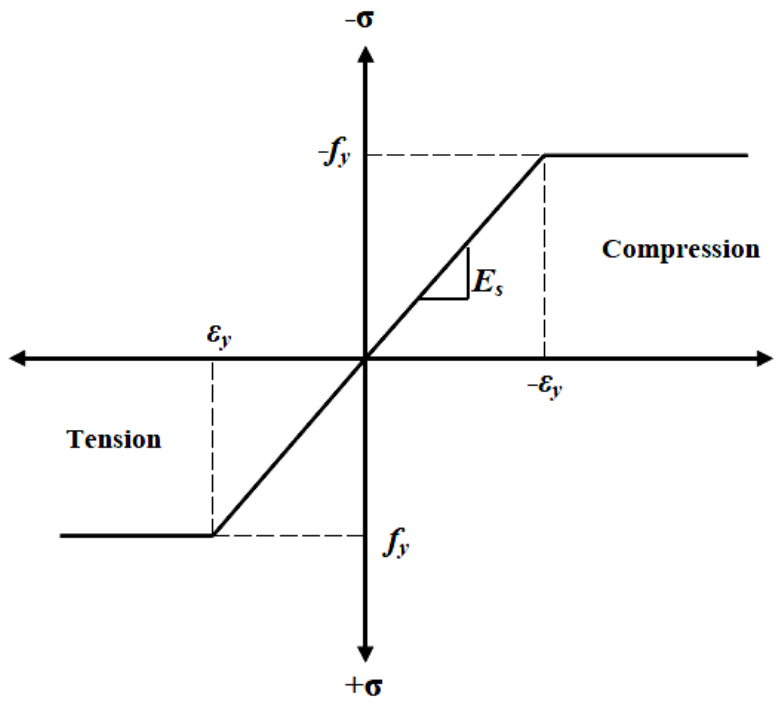

Fig.( 4-b): Stress-strain curve for steel reinforcement. 


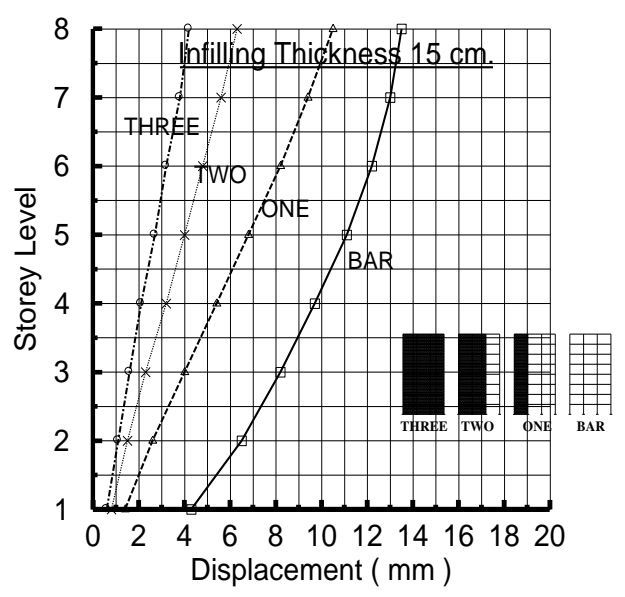

Fig (5): Effect of irregularity on lateral displacement.

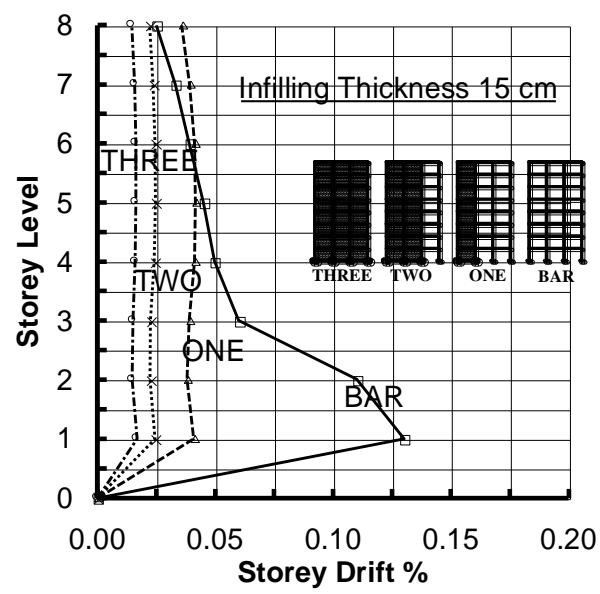

Fig ( 6): Effect of irregularity on storey drifts.

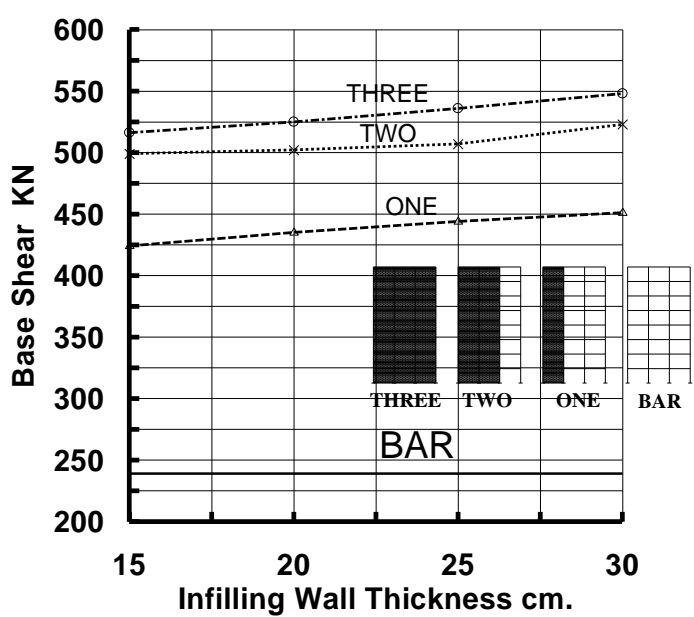

Fig (7): Effect of infilling wall thickness on base shear 


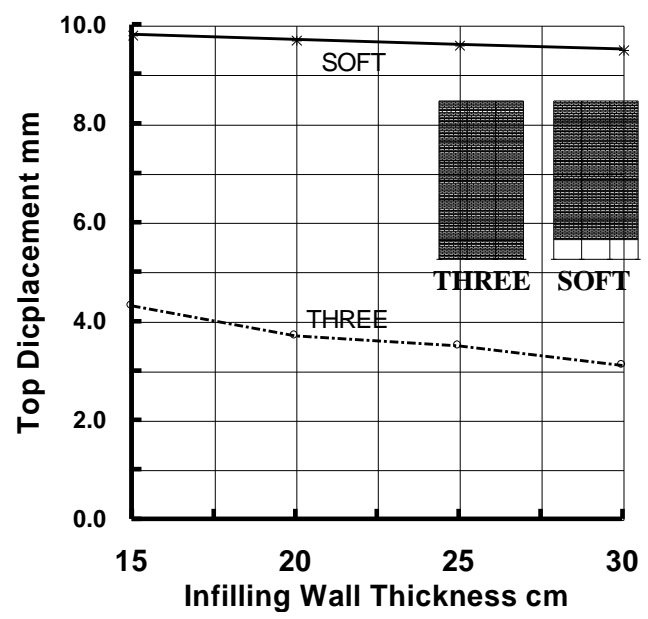

Fig( 8): Effect of soft storey on top displacement.

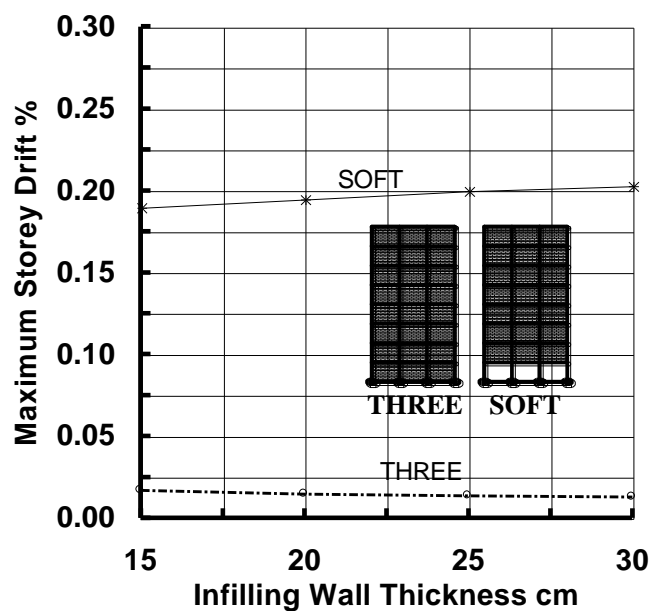

Fig( 9): Effect of soft storey on storey drifts.

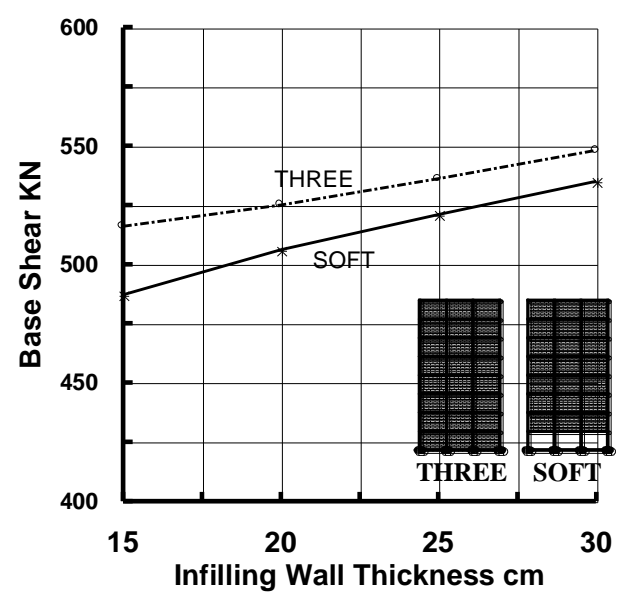


Fig (10): Effect of soft storey on base shear.

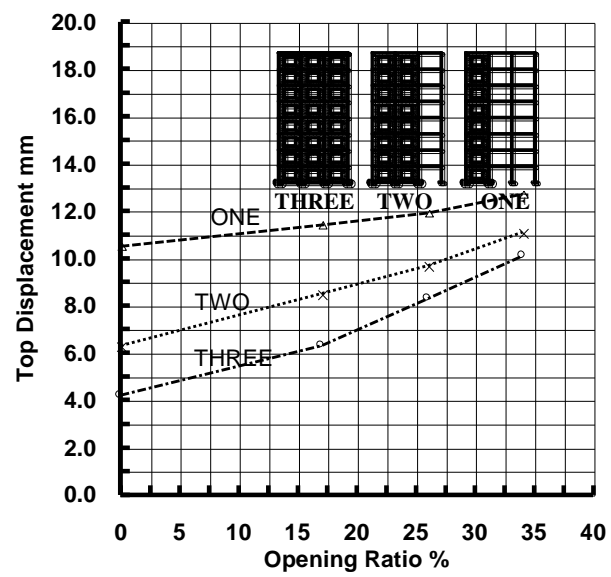

Fig (11): Effect of opening ratio on top displacement.

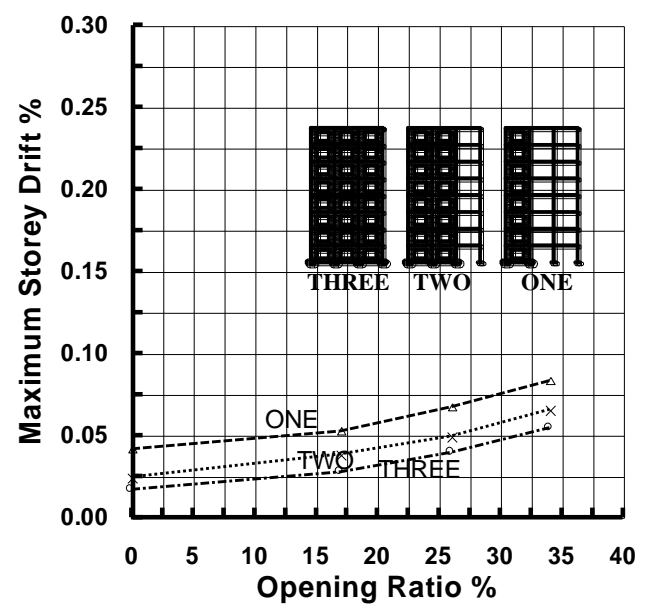

Fig( 12): Effect of opening ratio on storey drifts.

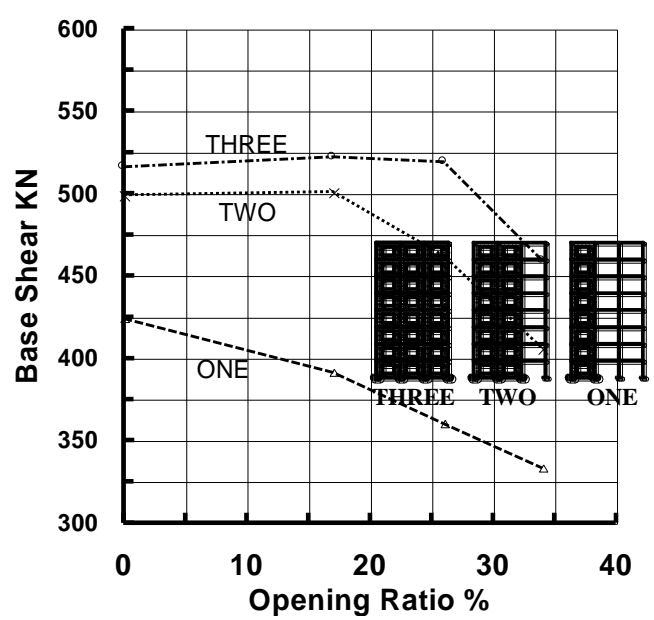

Fig( 13): Effect of opening ratio on base shear force. 
